\title{
O ABOLICIONISMO COMO RESISTÊNCIA AO EXTERMINIO DA POPULAÇÃO NEGRA
}

\author{
Priscila de Oliveira Xavier Scudder \\ Doutora em Educação pela Universidade Federal de Mato Grosso. Professora do \\ departamento de História da UFMT - Campus Rondonópolis \\ apriscilaxavier@gmail.com
}

\begin{abstract}
resumo: Tomando a obra "A Democracia da Abolição", da professora e filósofa Angela Davis como referência para a reflexão e também os dados do Mapa da Violência 2016 que se referem ao município de Rondonópolis/MT, este artigo propõe a discussão em torno das semelhanças entre a constituição e manifestação do racismo estadunidense e do brasileiro. Esta aproximação não tem o desejo de tomar modelos, mas de reconhecer a luta de homens e mulheres negros como pulsão para enfrentarmos nossos próprios desafios. 0 crescente aumento do extermínio da juventude negra, pobre e de periferia no Brasil, aponta para a urgência de organização de uma resistência popular, mas também intelectual, no sentido de enfrentar os discursos que legitimam a subalternidade, o encarceramento e até mesmo a escravização e extermínio do negro.
\end{abstract}

palavras-chave: Negro, Abolicionismo, extermínio, Racismo, Direitos Humanos. abstract: Taking the work of "A Democracia da Abolição", from Professor and Philosopher Angela Davis as a reference to the reflection and also the data from the "Map of Violence in 2016" that refers to the county of Rondonópolis/MT, this article proposes a discussion surrounding the things in common between the formation and manifestation of United States citizens racism and brazilian racism. This approach has no desire to take models, but to recognize the fight of men and women of color as a pulsing motion for the fights ahead and challenges. The incresing amount of extermination of the black, poor, suburban black youth in Brazil points to the urgency of a popular resistance organization but also an intelectual one in the sense of facing the narrative that legitimates the deminishing, the encarceration rates and even the enslavement and extermination of the black community.

keywords: Negro, Abolicionism, Extermination, Racism, Humans Rights. 


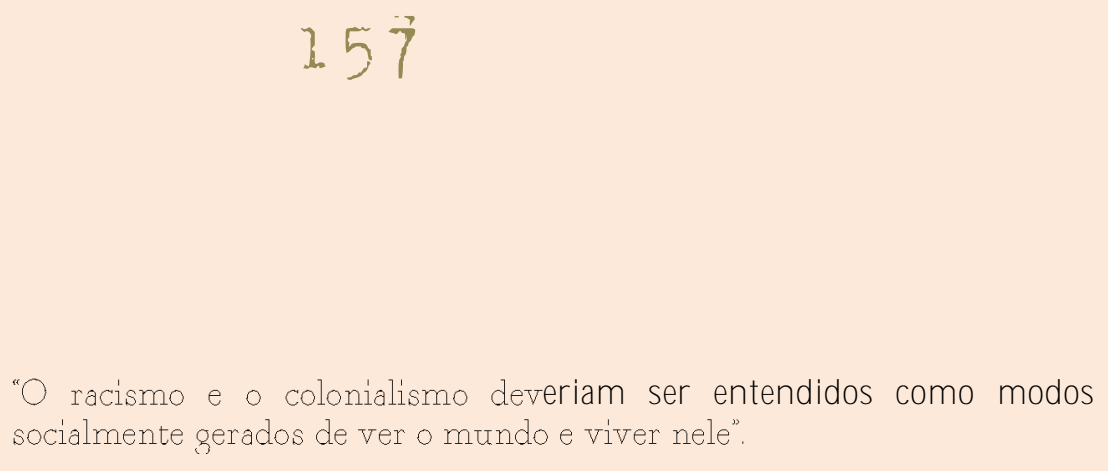

Frantz Fanon

\section{d}

e maneira muito recorrente, talvez sem escapatória, uma escrita, uma motivação para a reflexão, carrega em si as exigências de um corpo, suas imposições, os desconfortos que o mundo, as coisas e as circunstâncias à sua volta provocam. Denunciam sua exaustão, aborrecimentos, ressentimentos, batal has, desejos.

Durante longo período as universidade brasileiras trataram com evidente descaso as pesquisas e debates acerca das relações raciais, estudos que evidenciavam a condição subalterna do negro e/ou do indígena na sociedade. Não raros foram os autores que tentaram minimizar os efeitos da herança colonialista após a extinção legal do sistema escravista.

Tratados como objetos de estudos, folclorizados, na maior parte das vezes por intelectuais, autores e professores que se valiam, e se valem, de referenciais eurocêntricos e discursos colonizadores para pensá-lo, homens e mulheres negros (as), alçaram a outro patamar na escrita acadêmica, graças ao trabalho e a luta de pensadores negros que reivindicarem o direito de problematizar sua própria história, de denunciar o racismo de Estado, o racismo institucional, o racismo acadêmico, o racismo cotidiano, as políticas e legislações promulgadas para sua permanência em condição de inferioridade política, social, econômica, cultural, espiritual.

Sepor um lado, parece a al guns pesquisadores negros eindígenas, haver certa imposição de um "problema de pesquisa", e de um problema considerado menor, questão que já incomodou como se constituísse em um destino do qual não se escapa, em uma interrogação que se deve dar conta ao esgotamento, por outro, permitiu que se questionasse a legitimidade de narrativas hegemônicas de uma intelectualidade branca, conservadora e rançosa, apegada aos cânones de uma epistemologia racistas e capitalista, fundada em uma auto avaliação condescendente de superioridade.

A este respeito, é possível dizer que é coerente a advertência desconfiada de Malcon X apresentada na conhecida máxima: Não se tem uma revolução quando se ama o inimigo; não se tem uma revolução quando se está implorando ao sistema 
de exploração para que ele te integre. Revoluções derrubam sistemas, revoluções destroem sistemas. De igual maneira não se emancipa, não se revoluciona uma forma de ver o mundo e estar nele, não se descoloniza o pensamento, não se altera a perspectiva de pensar as populações ao Sul, utilizan do modelos arcaicos de estantes coloniais. Árdua ou não, a tarefa de interpretação dos discursos que cobrem a história dos oprimidos não pode ser realizada com base exclusiva, hegemônica, em conceitos criados eaplicadores unilateral mente pelos opressores, como o de Direitos Humanos.

Há algum tempo a simples menção ao termo "Direitos Humanos", suscita a desconfiança de que atrás dele ecoará um manifesto em defesa de criminosos ou grupos que se assemelhem. A pesar disto, aquele ocupados na defesa dos direitos de pessoas em situação devulnerabilidade erisco social, dos ditos desviantes, refugados, redundantes e descartáveis sabem que os avanços no combate as diferenças e desigualdades sociais, em assegurar condições de existência dignas aos "fronteiriços" elou marginalizados, foram de pequena monta, quem sabe, considerada a populac, ão cada vez maior de desamparados, foi mesmo inexpressivo. Diante dos discursos que atacam o próprio termo e por outro lado do aprofundamento dos problemas sociais, pensamos em iniciar nossa reflexão questionando a própria efetividade e história do conceito.

O colonialismo europeu, através da escravização que o caracterizou, trouxe a partir de 1492, um imenso contingente de africanos escravizados para a A mérica, "aproximadamente 13 milhões de pessoas" (A LVES, 2008), destes, aproximadamente 45\% eram trazidos para o Brasil. Provavelmente encontramos nestes números, a razão do país figurar no posto de nação com a maior população negra fora da Á frica.

Para justificar a escravização do negro as metrópoles européias e a empresa colonial recorreram a todo tipo de artifício legitimador: Deus e a ciência ofereceram os mitos e as teorias necessárias para o crime ultramarino.

Não foi por arrependimento da injustiça cometida, por problemas de consciência ou moral, tampouco por benevolência repentina, que negros e negras tiveram sua humanidade devolvida. A s lutas contra a escravização nasceram junto com o próprio colonialismo.A s resistências se erguiam no enfrentamento cotidiano, nas táticas elaboradas no espaço do próprio corpo e no corpo de uma coletividade, nos suicídios, abortos, aquilombamentos, associações e irmandades negras, compras de alforrias, etc. De fato, o decreto do fim do tráfico negreiro em 1865 não alcançou a muitos, tampouco lhes roubou o protagonismo, a memória permitiu que a herança ancestral fosse transmitida. Tal decreto, movido por interesses que não trataremos nesta escrita foi insuficiente, ao ponto de estarmos na atualidade, e a nível global, presenciando o aumento de discursos e práticas racistas, do encarceramento, do trabalho escravo e do extermínio da população jovem negra.

Da Revolução dos N egros no Haiti aos demais movimentos por liberdade protagonizados por africanos e nativos escravizados no continente americano e ao

SCUDDER, F. O. X. O abolicionismo camo resistência ao extermínio da população nešra.

alouquerque: revista de historia. val. 9, n. 17, jan.-jul. de 2017. p. 156-175. 
redor do mundo, resta o desafio da reflexão e insurreição contra o patriarcado, 0 racismo, a escravização, o encarceramento, ranços da mentalidade colonialista que ainda vigoram e que têm destinado ao negro uma condição e lugar na história e no imaginário social ainda de subalternidade.

Sobre o lugar de onde parte nosso olhar, podemos dizer que Rondonópolis é uma cidade do sudeste do estado de Mato Grosso, estado que integra o Centro-O este brasileiro. Sobre a formação e organização de seu espaço pelo Estado, tem-se notícia que deu-se por volta do século X IX , com a abertura do território pelos bandeirantes com o intuito de explorar minas auríferas e madeiras e manter o domínio e a segurança do território no Brasil Colônia. Com a chegada dos bandeirantes, teve início o processo do fluxo migratório e o surgimento dos primeiros povoados urbanos nos arredores das explorações diamantíferas. A ocupação humana da região era uma forma de garantir a geopolítica territorial inicial para o governo central.

A fronteira agrícola subsidiada pelo Estado a partir de 1930 faz parte do contexto das políticas "Marcha Para o Oeste" instituídas pelo Presidente Getulio V argas. A criação dos eixos rodoviários das BRs-364 e 163 abriu caminhos para 0 processo de colonização, de urbanização e de ocupação humana em Mato Grosso.

A Marcha para o Oeste, a expansão da fronteira agrícola, foi marcado ainda pela idéia de "vazio demográíco", que ao ignorar as nações indígenas que habitavam a região, a população quilombola, ribeirinha e outros andantes, consideraram as áreas de Mato Grosso, sem absolutamente nenhum morador.

Deste modo é possível afirmar que "atos de violência" (de racismo, de preconceito de classe, etc.), marcam aquilo que se costumou chamar de "fundação de Rondonópolis". O que se assistiu foi a dizimação de diversas nações indígenas e mesmo sua remoção compulsória para o Parque do X ingú, indicando o privilégio do agronegócio sobre práticas de vida ancestrais.

A força de trabalho utilizada nestas terras foi, em um primeiro momento, marcada pelo regime de escravização do negro, primeiramente empregado na exploração dos garimpos, na extração da erva-mate, da poaia e depois na agroindústria canavieira, ainda empregada hoje nas fazendas dos senadores Blairo Maggi, Ronaldo Caiado e outros latifundiários escravocratas.

Geograficamente, Mato Grosso é marcado por grandes áreas de cerrado, planícies do pantanal e floresta pré-amazônica. Entretanto, estes diferentes biomas, têm sofrido intenso topocídio, através do predomínio do agronegócio, que além de primar por latifúndios, tem nos últimos anos diversificado suas atividades e poder, através da industrialização, da ocupação de cargos políticos e da venda de grande quantidade de terra à investidores estrangeiros.

Ao longo do tempo. Rondonópolis transformou-se numa parada exclusiva dos bem-sucedidos donos do capitali empresarios, grupos agropecuarios e grandes produtores rurais. E a este grupo que se permite desfrutar das novas tecnicas de produc, ão e do conforto propiciados pelo status burgue^s; o restante, uma

SCUDDER, F. O. X. O abolicionismo como resistêneia ao extermínio da população nešra.

alouquerque: revista de historia. val. 9, n. 17, jan.-jul. de 2017. p. 156-175. 
populac ão ano`nima, afrodescendente, que com seu trabalho, também é forjadora do crescimento da cidade, assiste como expectadora ao progresso que nela acontece. pois não lhe é reservado saborear a sua "fatia do bolo'. É, sem dúvida, a concretizac, ão do mito do progresso a qualquer custo!

N esta terra onde se ergue a fortuna de grandes latifundiários, não há lugar para todos, e não sem razão a escravização, a criminalização, o encarceramento e mesmo o extermínio da população negra tem sido um recurso empregado com constância, no que se entende como enfrentamento à sua violência "natural".

Na obra "A Democracia da Abolição: para além do império, das prisões e da tortura". Angela Davis apresenta, entre outras coisas, seus esforços para teorizar a relação entra a prisão e a escravidão e encontramos nela indícios que permitem pensar o atual momento sócio-político e cultural brasileiro e os discursos políticosmidiáticos dirigidos contra a população negra.

$\mathrm{N}$ a obra citada, a autora faz um breve recuo no tempo para contar que

Logo depois da Guerra da Secessão, o Sul dos Estados Unidos, sofreu um processo de democratização espantoso e utópico, embora tragicamente efêmero. As tropas da união foram posicionadas no Sul, a fim de garantir a segurança dos negros enquanto eles iam às urnas. Negros foram eleitos senadores. Faculdades foram abertas. Uma vibrante esfera política negra começou a emergir. Esse breve período passou a ser conhecido como a "Reconstrução". Dentro de uma década, entretanto, a reconstrução foi interrompida, e um processo de retrocesso à escravidão teve início. Legisladores brancos sancionaram um conjunto de leis que obrigava os negros colocados em liberdade a se tornarem criados contratados por meio de sua criminalização. As prerrogativas dos ex-donos de escravos foram legisladas e legalizadas nas abomináveis "Blacks Laws" (Leis dos Negros). Uma vez na prisão, os condenados eram arrendados ou alugados por honorários ínfimos a empresários particulares do novo Sul. Esse processo ficou conhecido como sistema de locação de mão de obra prisional, e os historiadores vão longe ao afirmar que isso foi "pior que a escravidão". As leis negras do Sul transformaram negros livres em criminosos, de forma que sua mão de obra pudesse ser explorada de maneira ainda mais voraz e predatória do que quando eles haviam sido escravizados. 0 sistema de locação de mão de obra prisional tornou-se um dos mecanismos mais lucrativos para o controle simultâneo, junto com a manipulação do trabalho livre negro e a exploração desenfreada. Consequentemente, os negros entraram numa esfera pública da democracia norteamericana como inferiores e desiguais. A democracia para os negros fora contida no mesmo momento em

SCUDDER, F. O. X. O abolicionismo como resistência ao extermínio da população nešra.

alouquerque: revista de historia. val. 9, n. 17, jan.-jul. de 2017. p. 156-175. 
que fora prometida: na abolição da escravidão. Com a abolição da escravidão, os negros deixaram de ser escravos, mas imediatamente se tornaram criminosos - e, como criminosos, tornaram-se escravos do Estado!

A experiência estadunidense pode nos auxiliar a pensar a brasileira. A qui como lá, as leis abolicionistas foram promulgadas após lutas longas e intensas de homens e mulheres escravizados. Da morte por degolamento de Zumbi (nascido livre), pelas mãos da Coroa Portuguesa em 1695 à assinatura da Lei Á urea, cento e noventa e três anos transcorreram. 0 tempo passado entre estes acontecimentos é deveras significativo. Por um lado se opõe a ideologia propagada da "mansidão" do negro em relação a sua escravização e por outro confirma a aquiescência das metrópoles européias com a manutenção deste sistema e seu empenho em ignorar e desmantelar qualquer movimento de resistência e libertação.

Apesar de não termos experimentado um período de "Reconstrução", a abolição da escravidão no Brasil também veio acompanhada de um ideário de manutenção de injustiças, afinal, não se deu acompanhada de políticas de inclusão do negro na sociedade e sequer admitiu a utilização de sua mão-de-obra nas atividades em que detinha expertise 0 período seguinte ao da abolição foi marcado pela abertura à imigração e a ocupação dos postos do mercado por mão-de-obra branca, pela difusão de teorias racialistas vindas da Europa e da previsível criminalização do negro. A ssim, nem a ordenação da extinção do tráfico e comércio negreiro, nem a promulgação da Lè Áurea, garantiram aos negros e negras brasileiros uma emancipação real, posto que ao mesmo tempo que interesses econômicos declaravam o tráfico negreiro extinto/imoral, um arcabouço "científicomoral" era tecido para mantê-lo na condição de subalternidade.

Diante deste cenário, podemos afirmar que a monarquia brasileira após a promulgação da Lei Á urea, e posteriormente à Declaração da Independência, assim como as elites políticas e econômicas brasileiras, adeptas ao colonialismo e a seus pressupostos, ao ocuparem o poder durante a república, mantiveram um discurso racista e criminalizador em relação a população negra, assim que 0 argumento de Angela Davis sobre a democracia do "abolicionismo", nos parece não apenas razoável, mas a única saída frente ao racismo de Estado que se verifica em um e outro país.

A o analisar as consequências do fim do período chamado de "Reconstrução" e as decisões políticas do Estado norte-americano expressas através das "Blacks Laws". Davis elenca como este programa promoveu a criminalização da população negra. $\mathrm{N}$ os deteremos sobre oito de suas indicações, pois pensamos que podem servir como ponto de partida para pensarmos os não-ditos da história de africanos

\footnotetext{
1 DAVIS, Angela Y. A Democracia da Abolição: para além do império das prisões e da tortura. Rio de Janeiro: DIFEL, 2009, p. 9, 10.
}

SCUDDER, F. O. X. O abolicionismo como resistêneia ao extermínio da população nes̆ra.

albuquerque: revista de historia. val. 9, n. 17, jan.-jul. de 2017, p. 156-175. 
e brasileiros escravizados e posteriormente libertos no Brasil. Consideramos que podem auxiliar ainda no trabalho de cartografar a atualidade em busca de indícios que nos permitam desembaraçar as linhas que têm estreitado, acanhado, sufocado, exterminado a vida da população negra.

Segundo Davis, a primeira consequência da criminalização do negro nos EUA foi,

privar o negro do direito ao voto. A inda hoje, um total de sete estados exclui permanentemente ex-presidiários do direitos ao voto. Sete outros estados também privam do direito ao voto certas categorias de ex-presidiários (isso é determinado de acordo com o tipo de crime que eles supostamente cometeram), 33 estados privam de direito ao voto pessoas em liberdade condicional e 48 estados privam do direito ao voto os presos, sendo as únicas exceções o Maine e V ermont².

Sobre esta primeira consequência apontada por Davis, podemos dizer que apesar de sabermos que no Brasil até 1934, mulheres, negros, pobres e analfabetos não tinham direito ao voto, é preciso reconhecer que uma lacuna considerável persiste na compreensão da história da política brasileira. Por um lado estudiosos (a maioria branca), não encontraram evidências de que a raça tenha impacto sobre a política no país, por outro, não estabeleceu-se ainda a relação entre o aprisionamento e a restrição do voto da população negra. Este é um território em que precisamos empreen der esforços de pesquisa. N este sentido, a perspectiva de Davis apresentase como inspiração.

Por ora, podemos encontrar sinais desta relação na própria Constituição Brasileira de 1988, que no artigo 15, inciso III, afirma que são impedidos de votar apenas os que, no dia da votação, tiverem contra si condenação criminal transitada em julgado, enquanto durarem seus efeitos no Brasil. A ssim, os presos provisórios e os adolescentes internados, por não terem os direitos políticos suspensos, também têm o direito de votar. 0 próprio TSE informa que,

No dia 2 de março de 2010, foi aprovada pelo Plenário do TSE a Resolução n- 23219, que dispõe sobre a instalação de seções eleitorais especiais em estabelecimentos penais e de internação de adolescentes para viabilizar 0 voto de presos provisórios e de jovens em medida socioeducativa de internação. Os Tribunais Regionais Eleitorais (TREs) de cada Estado e do Distrito Federal, deacordo com a determinação do TSE, devem coordenar com os respectivos juízes eleitorais a criação de seções eleitorais especiais

\footnotetext{
2 DAVIS, Angela Y. A Democracia da Abolição: para além do império das prisões e da tortura. Rio de Janeiro: DIFEL, 2009, p. 14, 15.

SCUDDER, F. O. X. O abolicionismo como resistência ao extermínio da população neưra.

albuquerque: revista de historia. val. 9, n. 17, jan.-jul. de 2017, p. 156-175.
} 


\section{3}

em estabelecimentos penais e em unidades de internação de adolescentes. (TSE).

Ocorre que além de garantir o direito ao voto apenas aos prisioneiros provisórios, a própria legislação limita sua participação no pleito, ao responsabilizar o adolescente ou jovem que está em um centro de reabilitação e que já tenha completado os 16 anos, pelo requerimento de cadastramento eleitoral e recebimento do título de eleitor. Qualquer pesquisador elou pessoa um pouco mais atenta a realidade dos sistemas prisional e socioeducativo, tem ciência que o direito à saúde, educação, manutenção dos laços de amizade e familiaridade, de preservação de integridade física, de atendimento individualizado, não são respeitados no interior das instituições de fechamento, e sabe também que a pobreza e a prisão no Brasil tem cor, e se olharem para estas instituições e não conseguirem responder positivamenteà pergunta de Deleuze (1992), ao oficial de perícia "para qual problema a prisão é a solução"? podem ter aí a constatação de que reivindicar o direito ao voto em uma situação de encarceramento é de todo uma ficção.

O diagnóstico sobre o perfil da população carcerária brasileira, apresentado no documento "Mapa do Encarceramento: os jovens do Brasil", afirma que

Segundo dados do Sistema Integrado de Informação Penitenciária (InfoPen), os jovens representam 54,8\% da população carcerária brasileira. Em relação aos dados sobre cor/raça verifica-se que, em todo o período analisado (2005 a 2012), existiram mais negros presos no Brasil do que brancos. Em números absolutos: em 2005 havia 92.052 negros presos e 62569 brancos, ou seja, considerandose a parcela da população carcerária para a qual havia informação sobre cor disponível, 58,4\% era negra. Já em 2012 havia 292242 negros presos e 175536 brancos, ou seja, 60,8\% da população prisional era negra. Constata-se, assim, que quanto mais cresce a população prisional no país, mais cresce o número de negros encarcerados.

Certamente que o estabelecimento da relação entre o encarceramento da população negra e a retirada de seu direito ao voto car ece de maiores estudos, mas em uma primeira incursão, parecenos que estamos diante de algo plausível e que investigaremos mais detalhadamente em estudo posterior.

A inda sobre as consequências da criminalização do negro, Davis sugere que

a prisão se constitui em um mecanismo de apropriação da riqueza dos afro-americanos, não apenas através da exploração da mão de obra prisional, mas da apropriação da riqueza social. Davis ser efere

SCUDDER, F. O. X. O abolicionismo como resistência ao extermínio da população nešra.

albuquerque: revista de historia. val. 9, n. 17, jan.-jul. de 2017, p. 156-175. 
aos recursos dos norteamericanos negros para manterem as suas comunidades: escolas, igrejas, propriedades privadas, etc. Em nenhum momento, dada a quantidade exorbitante de negros nas prisões, a riqueza social retorna às comunidades negras, sendo excluída por meio da privação político-econômica e da exclusão. Ainda hoje todos os 50 estados dos EUA impedem que exdetentos adquiram licenças estaduais. Isto significa que eles são de facto excluídos de muitos, se não da maior parte, dos empregos 3 .

Quanto a este quesito, parece que o número de escolas no Brasil mantidas por comunidades, associações eirman dades negras, éproporcionalmenteinferior ao números de escolas afro-americanas, ainda assim há registros de que durante a década de 1930, a Frente Negra Brasileira, esforçou-se em organizar cursos de al fabetização para adultos e crianças negras e estabeleceu como meta a edificação de escolas próprias. Em 1934, o jornal A V oz da Raça traz a seguinte afirmação:

A escola da FN B. Que sob a direção do dr. Francisco Lucrécio, auxiliado pela sta. Celina Veiga, os quais vem dedicando seus maiores esforços para educar e preparar as crianças - o elemento básico formador de uma nacionalidade vigorosa, física e moralmente - a criança de hoje, o homem de amanhã. Eis porque aFN B. mantem as aulas noturnas: para instrurir não só as crianças, mas como os adultos, os quais ten do as suas obrigações cotidianas, poderão frequentar as aulas (.... Esta é mais uma glória para a FN.B. em possuir em seu seio um departamento de combate ao analfabetismo ${ }^{4}$.

Neste cenário, partilhamos afinidades com a condição do negro estadunidense, quanto a dupla extração da riqueza social. Em Mato Grosso temos o exemplo da construção da Igreja de São Benedito, erguida pela resistência negra ao mesmo tempo que seus braços davam conta da obra oficial da Igreja do Rosário, construções que hoje servem de locais de visitação na capital do estado.

U ma terceira consequência da criminalização do negro, seria a rotulação social, ou seja,

uma vez que um norte-americano negro tenha estado na prisão, ele (ou ela) será permanentemente rotulado. Conforme estudos

\footnotetext{
3 DAVIS, Angela Y. A Democracia da Abolição: para além do império das prisões e da tortura. Rio de Janeiro: DIFEL, 2009, p. 15.

${ }^{4}$ ARAÚJO, Márcia. A Escola da Frente Negra Brasileira na Cidade de São Paulo (1931-1937). São Paulo. [sn], Dissertação (Mestrado em Educação) - Faculdade de Educação, USP, 2008

SCUDDER, F. O. X. O abolicionismo como resistência ao extermínio da população nešra.

alouquerque: revista de historia. val. 9, n. 17, jan.-jul. de 2017. p. 156-175.
} 
recentes comprovam, é mais difícil para ex-prisioneiros negros reingressarem na sociedade do que para ex-prisioneiros brancos 5 .

Estudos do Instituto Brasileiro de Geografia e Estatística - IBGE já demonstraram exaustivamente, e ao longo de décadas, que a população negra além de ocupar cargos subalternos no mercado de trabalho, quando exerce a mesma função que um branco, o tratamento e a remuneração são desiguais, o que parece reproduzir-se quando se cartografa o modo como o mercado trata a mão-de-obra de ex-presidiários.

Em artigo publicado na revista Brasil Debate, A ndré Cardoso, economista do Departamento Intersindical de Estatística e Estudos Socioeconômicos - DIEESE, afirma que

Estudos Socioeconômicos) pelo Sistema PED (Pesquisa de Emprego e Desemprego), os negros eram maioria na População Economicamente A tiva - PEA, nas regiões analisadas: Fortaleza $(83,0 \%)$, Recife $(77,7 \%)$ e Salvador (92,4\%). Em São Paulo eram $38,4 \%$, e, em Porto A legre, ficava em apenas $13,3 \%$. A pesar desse número expressivo, independentemente do peso relativo da população negra, a proporção de negros desempregados é sempre superior a de negros ocupados. Constatou-se também que as formas de inserção dos trabalhadores negros ocupados ainda são marcadas pela precariedade. Mesmo com o crescimento do emprego mais formalizado, a participação relativa dos negros é maior nas ocupações nas quais prevalece a ausência da proteção previdenciária e, em geral, os direitos trabalhistas são desrespeitados. (CARDOSO, 2015).

artigo intitulado "O fosso entre brancos e negros no mercado de trabalho", publicado pela revista Carta Capital, confirma e analisa os resultados dos censos e pesquisas realizados pelo IBGE e DIESSE, nele verifica-se o racismo presente nas relações de trabalho, ao indicar que

0 rendimento dos trabalhadores de cor preta ou parda cresceu $52,6 \%$ entre 2003 e 2015. Entre os trabalhadores de cor branca, 0 crescimento foi de $25 \%$. 0 expressivo crescimento verificado nos últimos 13 anos, período que engloba os governos Lula e Dilma Rousseff, porém, não foi suficiente para reverter o quadro de

\footnotetext{
${ }^{5}$ DAVIS, Angela Y. A Democracia da Abolição: para além do império das prisões e da tortura. Rio de Janeiro: DIFEL, 2009, p. 15.

SCUDDER, F. O. X. O abolicionismo como resistêneia ao extermínio da população neưra.

albuquerque: revista de inistoria. val. 9, n. 17, jan.-jul. de 2017, p. 156-175.
} 
desigualdade racial. Anunciados nesta quinta-feira 28 pelo Instituto Brasileiro de Geografia e Estatística (IBGE), os dados fazem parte da Pesquisa Mensal de Emprego (PME). Os trabalhadores ocupados de cor preta ou parda ganhavam, em média, em 2015,59,2\% do rendimento recebido pelos trabal hadores de cor branca. O IBGE destacou, porém, o fato de que, em 2003, o percentual não chegava à metade (48,4\%). (..) A maior disparidade entre os rendimentos de brancos e negros observou-se na região metropolitana de Salvador, onde os trabal hadores pretos ou pardos recebem apenas $48 \%$ dos rendimentos dos brancos. Em 2003, o índice era ainda menor, só $323 \%$. A diferença fica mais gritante quando se considera que Salvador é a cidade com maior número de negros e pardos no Brasil, quase $80 \%$ da população do município, segundo dados do Mapa da População Preta e Parda do Brasil, divulgados em 2010.

A criminalização do negro brasileiro, assemelha-se a do negro estadunidense retratada por Davis. Sujeito a um discurso queo desqualifica a participar dos espaços sociais, é contra estes discursos e os dispositivos de Estado que precisa se insurgir, tanto para garantir sua existência biológica, quanto política e cultural.

A cerca do quarto desdobramento provocado pela criminalização da população negra, Davis observa

a existência de um contrato racial, que se refere à realidade sociopolítico-econômico-cultural na qual é mais vantajoso ser branco do que negro, pois todas as normas, são de facto normas brancas. Dentro do contrato racial, a punição social é aceita por ser aplicada principalmente aos negros. Assim toleramos uma sociedade altamente punitiva, pois sua punição é executada neles e não em nós. Para Davis, a indústria do complexo carcerário também contribui para a dominação das minorias raciais ao domesticar a imaginação cívica dos norte-americanos bran $\cos ^{6}$.

A s notícias de ações de milicianos e de outros grupos de extermínio, as ações desastrosas das maquinarias violentas do Estado, como as que resultaram no Carandiru, no Complexo de Pedrinhas no Maranhão, chacinas como as da Candelária, de Mogi das Cruzes, da Chatuba ou do Beco do Candeeiro, a visão dos jovens mortos atirados em uma caminhonete em Rondonópolis não comovem a sociedade e não impede o clamor pela redução da maioridade penal, pelo

${ }^{6}$ DAVIS, Angela Y. A Democracia da Abolição: para além do império das prisões e da tortura. Rio de Janeiro: DIFEL, 2009, p. 16.

SCUDDER, F. O. X. O abolicionismo como resistêneia ao extermínio da população nes̆ra.

albuquerque: revista de historia. val. 9, n. 17, jan.-jul. de 2017, p. 156-175. 
estabelecimento da pena de morte ou de penas mais duras, nem os linchamentos, porque em todos estes casos a maioria dos corpos é negra.

U ma quinta decorrência é a existência do que Davis denomina de

\begin{abstract}
violência ritualística, que purga e expia a ordem social. 0 sistema carcerário torna natural a violência decretada contra as minorias raciais ao institucionalizar uma lógica circular viciosa: os negros estão presos porque são criminosos, eles são criminosos porque são negros, e se eles estão presos é porque merecem. A s cadeias, sob mais de um aspecto, institucionalizaram os linchamentos da virada do século XX, sendo a implantação das "Jim Crow Laws" o ataque mais cruel eviolento imposto à população negra? .
\end{abstract}

As cadeias têm se constituído em uma das ferramentas utilizadas pelo Estado para eliminar os refugados, aqueles, como indica Bauman, que não têm assento no ônibus do progresso. Em frente a seus portões, nas filas de visita, nas fichas de identificação, estão denunciadas a classe social e a cor de seus moradores, assim como as reincidências apontam para o modo como suas vidas circulam ao redor da instituição e da violência que impõem e sofrem. De fato, quem observa a prisão atentamente, percebe que se trata de um edifício segregacionista, destinado a um determinado público, aquele sobre quem o olhar panóptico repousa.

U m sétimo resultado da criminalização do negro, foi a coerção sexual.

Para Davis a prisão se serve do abuso sexualizado para o controle social. A masculinidade agressiva dos presidiários se iguala à coerção sexual impetrada pelos guardas e diretores. Sob esse aspecto, o sistema carcerário constitui um regime caracterizado pela violência sexual, queé ao mesmo tempo racistå

\footnotetext{
7 "Jim Crow Laws", (O nome "JIM CROW" era dado frequentemente aos escravos negros norteamericanos), conjunto de leis quee chancelou à política de segregação racial que vinha sendo adotada, sobretudo, pelos estados do sul do país. Nesse sistema, não se permitia, por exemplo, que os negros utilizassem os mesmo banheiros ou bebedores públicos que os brancos ou mesmo frequientassem os mesmos restaurantes, clubes e escolas. A "legalização" da segregação racial nos EUA, muito se assemelhou ao regime de apartheid que vigorou na África do Sul até os anos 90. Era um sistema cruel para os negros, já que eles ficavam oficialmente excluídos das mesmas vantagens públicas e privadas concedidas aos cidadãos brancos. Não tinham o mesmo acesso à educação, aos clubes (lazer), aos meios de transporte, aos cinemas, ao trabalho, aos restaurantes e por aí vai. Eram cidadãos de segunda classe e até hoje isso se reflete na estrutura sócio-econômica daqueles países, em que os negros, em sua maioria, costumam morar em "guetos" pouco desenvolvidos, possuem baixa escolaridade e exercem funções quase sempre braçais de pouca rentabilidade.
}

8 DAVIS, Angela Y. A Democracia da Abolição: para além do império das prisões e da tortura. Rio de Janeiro: DIFEL, 2009, p. 17.

\footnotetext{
SCUDDER, F. O. X. o abolicionismo como resistência ao extermínio da população nes̆ra.

albuquerque: revista de historia. val. 9, n. 17, jan.-jul. de 2017, p. 156-175.
} 
Sobre este aspecto cabe dizer que a maior parte dos estudos sobre violência sexual em instituições prisionais, diz respeito às penitenciárias femininas, mas é sabido que homens aprisionados impõe e sofrem violências sexuais. Caso ocorrido no Centro Sócioeducativo Pomeri, em Cuiabá, capital do Estado de Mato Grosso, informaque

O adolescente RG teria sido colocado em uma cela com seis adolescentes acusados de estupro, por um agente penitenciário com quem havia se desentendido durante o plantão. 0 referido agente havia ordenado aos seis que o estuprassem. N otou-se que a transferência deRG foi impedida duranteo dia pela equipetécnica, mas que durante a noite ela se efetivou. Pela manhã o adolescente RG foi encontrado em suacela, com sinais de violência sexual, mas não "desejou" registrar queixa.

Proliferam notícias em diversas mídias sobre a violência sexual que ocorre entre os muros das prisões, famílias de prisioneiros insistem em notificar equipes técnicas e autoridades sobre a questão. A organização Human Rights $W$ atch ao examinar pela as condições prisionais no Brasil, constatou que

Prisioneiros homossexuais e transexuais enfrentam dificuldades particulares, na medida em que a discriminação contra eles é intensificada na sociedade hierárquica das prisões masculinas. A lguns prisioneiros homossexuais e transexuais estão confinados na Casa da Detenção de São Paulo, a maioria em uma pequena área no pavilhão cinco. Uma minoria desprezada pelo sistema penitenciário, eles não têm outra escolha senão conformar suas atitudes ao conjunto de "leis" não escritas estabelecidas por outros detentos. $N$ os dias de visita, por exemplo, eles têm que permanecer nas suas celas durante o dia todo; eles não podem mostrar-se por medo de aborrecer os visitantes. Se recebem visitas, eles só podem sair das celas cobertos. Cada prisão, e cada pavilhão na Casa de Detenção, tem algum tipo de regra diferente para os homossexuais, mas elas são todas similarmente degradantes e discriminatórias.

Entretanto, a sujeição sexual não se restringe aos prisioneiros homossexuais etransexuais. Presioneiros heterossexuais, jovens, novatos no sistema penitenciário, réus primários, "cagoetas", são vítimas potenciais, daquilo que parece ter se imposto como um ritual de iniciação, ou recorrendo à Goffman (1974), um "ritual de mortificação" das prisões.

SCUDDER, F. O. X. O abolicionismo como resistêneia ao extermínio da população nes̆ra.

albuquerque: revista de historia. vol. 9, n. 17, jan.-jul. de 2017, p. 156-175. 


\section{9}

A cerca da oitava sequela da criminalização do negro, ela seria caracterizada como

a repressão excessiva, já que o regime de institucionalização da prisão dentro de uma indústria incute na mente dos cidadãos a noção de que os presidiários são a um só tempo inevitáveis e indesejáveis. É uma forma lógica de lidar com o crime. N ós temos tantos presídios, porque nós os construímos, e tantos setores da sociedade investem em sua perpetuação. Os cidadãos, entretanto, não têm permissão para perguntar: 0 aprisionamento é a única maneira de tratar os crimes e as disfunções sociais? Os crimes são realmente resolvidos com os presídios? (... $)^{9}$.

As prisões se instituíram em nosso meio com "naturalidade", de modo regular e sob o signo de al go do qual não podemos dispor. A lgo inevitável, mas se a consideramos aceitável, é justo por sabermos a quem ela se destinada. Um olhar rápido para as prisões, estadunidenses ou brasileiras, e a cor de sua população parece explicar a razão.

Concordamos com Davis que estes desdobramentos da criminalização do negro são impedimentos

Para a autêntica democracia emergir (..), a democracia da abolição deve ser decretada - a abolição das instituições que promovem a dominação de um grupo sobre o outro. A democracia da abolição, é portanto a democracia que está por vir, a democracia que será possível se dermos continuidade aos grandes movimentos de abolição da história norte-americana, aqueles em oposição à escravidão, ao linchamento eà segregação. Enquanto a indústria do complexo carcerário persistir, a democracia norte-americana continuará a ser falsa. Uma democracia falsa desse tipo reduz o povo e suas comunidades à subsistência biológica mais crua, pois ela os exclui da lei e da sociedade organizada Não foi isso que vimos claramente em Nova Orleans, logo após a passagem do Katrina? (...) Uma existência tão carente pode ser ignorada e negligenciada, ou extinta com a impunidade, precisamente porque éa lei que a torna dispensável.A punição tem sido utilizada contra o corpo humano como se fosse este um corpo negro. A pena de morte sobrevive não como o último castigo, mas por ter sido

\footnotetext{
9 DAVIS, Angela Y. A Democracia da Abolição: para além do império das prisões e da tortura. Rio de Janeiro: DIFEL, 2009, p. 17. 
essencial mente uma forma de castigo contra a carne e a liberdade negras ${ }^{10}$.

Conforme dissemos anteriormente, parte da dificuldade em problematizar a criminalização do negro e sua permanência subalternizada nas diversas dimensões da vida social, no caso da sociedade brasileira, mas não apenas, se deve ao recurso contínuo a epistemologias e conceitos brancocentrados, insuficientes como o de Direitos Humanos. Tratado como um universalismo, fundado em um nascimento transcendente, posto ao mundo como se brotasse da/na natureza, permanece impregnado nas bocas e discursos até mesmo de militantes de movimentos sociais e partídos políticos que se situam em "um lugar" à esquerda. Ora. Grosfoguel" apontou o modo pelo qual ressoa neste conceito as antigas disputas travadas no estabelecimento das declarações do Direito dos Povos e dos Direitos dos Homens, nos séculos XVI e XVIII respectivamente, ambos forjados sem a participação daqueles que tinham sua humanidade questionada e que seriam alvo do receituário dos documentos.

O uso de conceitos obsoletos, impõe que construamos análises superficiais, ou que partamos de esquemas centrados no par causa-consequência-causa, ou seja começamos nossas interrogações de um su posto ponto de chegada, ou seja, ao invés da crítica ao sistema-mundo capitalista, ao aprofundamento da miséria, a crescente produção da miséria, do combate à aceitação e proliferação de discursos e práticas racistas, etc, discute-se reforma do sistema penitenciário e deunidades deinternação para jovens e adolescentes.

O conceito de Direitos Humanos não pode potencializar a vida e a luta de homens e mulheres negros (as), posto que o propósito de sua formulação, aquilo que justifica seu emprego ainda na atualidade, seu mito fundador, não foi e não éa defesa da dignidade de toda e qualquer forma de vida, de toda maneira de ver e viver no mundo, mas baseia-se sim no postulado da supremacia branca, e na indignação seletiva frente a certas guerras, certas "ditaduras", certos direitos à soberania, no combate à certos campos de concentração, certos genocídios, certas misérias. Evidenciam-se as razões que fazem com que o conceito seja visto com desconfiança ao ser utilizado em relação às questões relativas à população negra, às comunidades de periferia, e de seu uso não ser efetivo na luta contra o racismo, mas que ferramenta utilizar como metáfora libertadora? Por ora, propomos recorrer ao conceito de quilombo e ubuntú. Assim, que desejamos pensar fora deste envelhecido modelo hegemônico e como primeira experiência, voltamos à al gumas

${ }^{10}$ DAVIS, Angela Y. A Democracia da Abolição: para além do império das prisões e da tortura. Rio de Janeiro: DIFEL, 2009.

11 GROSFOGUEL, Ramón. Los derechos humanos y el antisemitismo después de Gaza. Universitas Humanística $\mathrm{n}^{\circ}$ 68, Colômbia, 2009, p.159

SCUDDER, F. O. X. O abolicionismo camo resistência a o extermínio da população neğra.

albuquerque: revista de inistoria. val. 9, n. 17, jan.-jul. de 2017, p. 156-175. 
práticas ancestrais, pois reconhecemos sua potência e validade, e encontramos U buntú e Quilombo como forças deque podemos nos valer.

Debatendo a possibilidade de definição e uso do conceito de Quilombo, de sua tomada como referência para o pensar a partir de práticas emancipatórias negras, A Imeida assevera que,

\begin{abstract}
se podereinterpretar criticamente o conceito e asseverar que a situação de quilombo existe onde há uma produção autônoma que não passa pelo grande proprietário ou pelo senhor de escravos como mediador efetivo, embora simbolicamente tal mediação possa ser estrategicamente mantida numa reapropriação do mito do bom senhor, tal como se detecta hoje em algumas situações de aforamentop ${ }^{2}$.
\end{abstract}

De fato, o conceito guarda uma mística própria, seu ritual de criação e recriação esteve e está ligado às urgências de se iniciar uma investida sistemática contra um sistema genocida. A lém de permitir o reconhecimento dos laços de fraternidade como tática e força política, da necessidade de pactuação de finalidades coletivas, o conceito conta a história de africanos escravizados e sequestrados para - Brasil, o que permite a quebra da tradução também hegemônica de uma história colonialista e colonizada. Sobre o conceito há al gumas definições que cabe conhecer, como a de Leite (2008: 965):

\begin{abstract}
A palavra "quilombo", que em sua etimologia bantu quer dizer acampamento guerreiro na floresta, foi popularizada no Brasil pela administração colonial, em suas leis, relatórios, atos e decretos, para se referir às unidades de apoio mútuo criadas pelos rebeldes ao sistema escravista e às suas reações, organizações e lutas pelo fim da escravidão no País. Essa palavra teve também um significado especial para os libertos, em sua trajetória, conquista e liberdade, alcançando amplas dimensões e conteúdos. 0 fato mais emblemático é o do Quilombo dos Palmares, movimento rebelde que se opôs à administração colonial por quase dois séculos.
\end{abstract}

Se observamos as periferias das grandes metrópoles brasileiras, as prisões e socioeducativos, as fazendas de Rondonópolis e a cor mão-de-obra escravizada que continuam mantendo, podemos relacionálas às antigas senzalas, aos guetos, e aí podemos concordar que o conceito de Quilombo, pode ser mais efetivo, entre outras

\footnotetext{
${ }^{12}$ ALMEIDA, A.W. Os quilombos e as novas etnias. In: LEITÃO (org.) Direitos Territoriais das Comunidades Negras Rurais. São Paulo: Instituto Socioambiental, 1999, p. 14-15.
}

SCUDDER, F. O. X. O abolicionismo camo resistêneia ao extermínio da população neưra.

albuquerque: revista de historia. val. 9, n. 17, jan.-jul. de 2017, p. 156-175. 
coisas, por vir carregado de um conteúdo de luta, de exigência de mobilização, éum conceito ativo, fisiológico, ligado ao direito à existência coletiva, ao direito à expressão cultural, espiritual, ao desenvolvimento de epistemologias próprias, etc. Indícios da positividade e combatividade que permeia o conceito pode ser percebido no fato de que,

As centenas de insurreições de escravos eas formas mais diversas de rejeição ao sistema escravista no período colonial fizeram da palavra "quilombo" um marco da luta contra a dominação colonial edetodas as lutas dos negros quese seguiram após a quebra desses laços institucionais. A Legislação Ultramarina em sua fase áurea definiu como sendo um quilombo a reunião de mais de cinco negros - tal era o potencial de revolta contido na união dos escravos. Quilombo e liberdade são, portanto, contrafaces de uma mesma realidade histórica. De um lado, as situações de força arbitrária e incontestável em que os "senhores" impunham a sua vontade por meio de atitudes explícitas ou dissimuladas, brandas ou violentas. De outro, as reações dos escravos e libertos, explícitas, sutis, violentas ou não, às diversas situações e regimes de autoridade. (LEITE: 2008: 965-966)

É Kabenguele Munangaㄹ, quem ensina sobre os rituais de entrada e pertencimento a um quilombo e lembra do caráter agregador de cada passo, da substituição da cultura particular a um grupo menor pela construção de práticas, símbolos, sentimentos, interesses com significado e efeito em uma coletividade maior, para Munanga

A palavra quilombo tem a conotação de uma associação de homens, aberta a todos sem distinção de filiação a qualquer linhagem, na qual os membros eram submetidos a dramáticos rituais de iniciação que os retiravam do âmbito protetor de suas linhagens e os integravam como co-guerreiros num regimento de super-homens invulneráveis às armas de inimigo ${ }^{14}$

Certamente, a organização dos Quilombos preocupava a metrópoles pois na prática propunha negação da sociedade oficial e a reafirmação da cultura e do estilo

\footnotetext{
${ }^{13}$ MUNANGA, Kabenguele. Origem e histórico dos quilombos em África. In: MOURA, C. (Org.) Os quilombos na dinâmica social do Brasil. Maceió: Edufal, p. 21-31, 2001.

${ }^{14}$ MUNANGA, Kabenguele. Origem e histórico dos quilombos em África. In: MOURA, C. (Org.) Os quilombos na dinâmica social do Brasil. Maceió: Edufal, 2001.
}

SCUDDER, F. O. X. O abolicionismo como resistêneia ao extermínio da população neưra.

albuquerque: revista de historia. val. 9, n. 17, jan.-jul. de 2017, p. 156-175. 
de vida africanos e brasileiros escravizados. A cerca do termo, Moura (1972), acrescenta que

Intui-se que os negros escravizados na África trouxeram o vocábulo "quilombo" para as Américas, onde assumiu novos sentidos em diferentes épocas e nas diversas regiões. No Brasil, 0 termo foi originalmente utilizado para designar um espaço e um movimento de resistência ao sistema escravocrata, composto predominantemente por negros enegras quefugiram eformaram núcleos paralelos de poder, produção e organização social. A gregando indígenas e brancos desertores, o quilombo (.) foi a expressão mais radical de ruptura com o sistema brasileiro latifundiário e escravista. a instituição legal da escravidão marcou o início da organização quilombola no país, não se pode, entretanto, imaginar que a sua proibição pôs fim aos quilombos. Mesmo quando escravizar tornou-se ilegal, as práticas opressoras continuaram se reproduzindo contra a população negra e daí a manutenção da sua resistência (MOURA, 1972).

A lém de propor o uso do conceito de Quilombo nas análises sobrea condição do negro frente às políticas de encarceramento, ações de extermínio e a situações de racismo, pensamos também no uso do conceito de U buntu, definido por Santos e Meneses (2009: 183), como

(...) categoria epistémica e ontológica do pensamento dos grtupos africanos que falam línguas Bantu, que significa ser em geral, relac, ões interpessoais e procura de uma harmonia cósmica (...). 0 ubuntu (.) representa uma alternativa epistemológica que pode contribuir para dar um outro sentido à vida humana e repensar a questão dos direitos humanos a partir de uma perspectiva holística.

Em artigo intitulado "Justiça Transicional na África do Sul: restaurando o passado, construindo o futuro". Pinto, apresenta a definiç̧̃a do conceito proposta por Desmond Tutu. Em tradução própria, afirma que para Tutu 
A definição deU buntu estáligadaà busca por harmonia social.Em suas palavras, "um ser humano só é um ser humano por meio de outros e, se um deles é humilhado ou diminuído, o outro o será igualmente" (... É a idéia de compartilhamento, de pertencimento a uma comunidade. ${ }^{15}$

Semelhante ao conceito de Quilombo, a coletividade é um imperativo que compõe o conceito de Ubuntu, e aí reside a abissal distância entre estes e o de Direitos Humanos, posto que esteúltimo pensa questões como dignidade, liberdade, fraternidade para um grupo exclusivo para a "comunidade branca" européia e admite para seu bem viver e estar no mundo, a exploração, confinamento, extermínio dos demais homens e mulheres, em especial indígenas e negros.

Como dissemos no início deste artigo, o lugar de onde nosso observamos a condição do negro na atualidade é a cidade de Rondonópolis. É na mídia local que lemos sobre o extermínio da juventude negra, é nela também que seus corpos mortos são exibidos sem cerimônia, é em suas ruas que os vemos constantemente parados e revistados sob ordens policiais. Também observamos que os números de prisioneiros confinados nas instituições de fechamento situadas no município, não cessa de crescer. Para tal situação contribui o fato da cidade se erguer entre latifúndios, multinacionais dedicadas à produção de veneno, nações indígena em luta pela sobrevivência, e com população negra utilizada como de mão-de-obra escrava.

Certamente, este panoramaé mais que suficiente para que possamos afirmar a insuficiência do conceito de Direitos Humanos no que tange ao reconhecimento e a proteção da vida de homens e mulheres negros (as). Parte das análises que pensam as prisões ao pautarem suas argumentações neste conceito, acabam propondo a reforma das prisões e socioeducativos, defendendo tão somente um tratamento mais digno e "humano" aos aprisionados, mas não assumindo o abolicionismo como urgência, posto que, via de regra, as perspectivas se acovardam na análise do racismo, do extermínio e do encarceramento como políticas deEstado, questão da qual A ngela Davis não foge e que os conceitos de Quilombo e U buntu transvaloram, enfrentam, interrogam.

15 PINTO, Simone Martins Rodrigues. Justiça transicional na África do Sul: restaurando o passado, construindo o futuro. In: Contexto Internacional. Vol.29 no.2. Rio de Janeiro: 2007, p. 405.

SCUDDER, F. O. X. O abolicionismo como resistêneia ao extermínio da população nes̆ra.

albuquerque: revista de historia. val. 9, n. 17, jan.-jul. de 2017, p. 156-175. 
Para encerrar, penso que a obra de Davis, sua experiência com a prisão, sua trajetória como mulher e intelectual negra, nos oferece indícios singulares para pensar a nossa própria história e o quanto a abolição do sistema prisional e de todas as instituições ligadas à dominação e extinção de negros e outros grupos é urgente!

"UBUNTU UNGAMNTU NGANYE ABANTU"

'Pessoas são pessoas através de outras pessoas"

(Ditado X hosa - língua materna de Nelson Mandela) 